\title{
Una Clase de CLASE y \\ un Despacho en el \\ Pasillo
}

\section{Enrique Fuentes Goyanes ${ }^{a}$}

\section{"Alea jacta est"}

Si uno atiende a los hechos de estos días del siglo XXI, le parecerá el comienzo de una etapa misteriosa, por lo diferente, insólita y con difíciles soluciones para todos, un buen momento para decir adiós al pasado.

Mi vida después de tantos años como profesor universitario dejará una impronta no solo entre las generaciones que pasaron por las aulas y los que alguna vez me tuvieron como intérprete de la cultura y sus avatares, sino también entre nuevas personas que nunca había conocido, y entre mis amigos y hermanos.

En un conjunto de certezas e inseguridades, como individuos nos seguiremos aferrando a soluciones enigmáticas, a mitologías antiguas y futuristas que reemplazarán, en mi caso, las reglas explícitas recibidas de la ciencia y de la educación, e incluso pueden estar lejos del sentido común, de la racionalidad de un sistema de normas y obligaciones que pocas veces llegaron a frenar mi libertad de pensar y actuar.

Para algunos de mis autores preferidos, la ciencia y el arte son dos dimensiones complementarias que orientan nuestra vida y nos hacen más responsables en el cambio cultural de la humanidad.

El análisis del cambio social y de las aportaciones científico-tecnológicas indica que es necesario tener en cuenta diversas teorías para potenciar el progreso de nuestros conocimientos y mejorar nuestras actitudes con nuestros compatriotas en un mundo que nos relaciona universalmente. Esta investigación, basada en la reflexión y en la introspección, no tiene por qué ser corporativa ni al servicio de poderes fácticos, y proporciona otra conciencia a los profesores en su actividad social y en su vida personal, haciendo de ambos ámbitos una vocación y un deseo de ser felices como destino. La crisis económica después del desenfreno libertino puede ser que nos abra la puerta a una complacencia post-materialista.

\footnotetext{
${ }^{a}$ Professor titular d'universitat. Departament de Pedagogia. Universitat Rovira i Virgili - Tarragona
} 
Minimizar nuestras posibilidades y ambiciones será una necesidad para adaptarnos a un mundo de recursos limitados que nos avisan del surgimiento de una naturaleza humana más perfectible. Me gustaría saber distinguir que fuerzas sociales impulsan el futuro común, si serán justas con todos los ciudadanos y si alguna verdad puede ser compartida en paz.

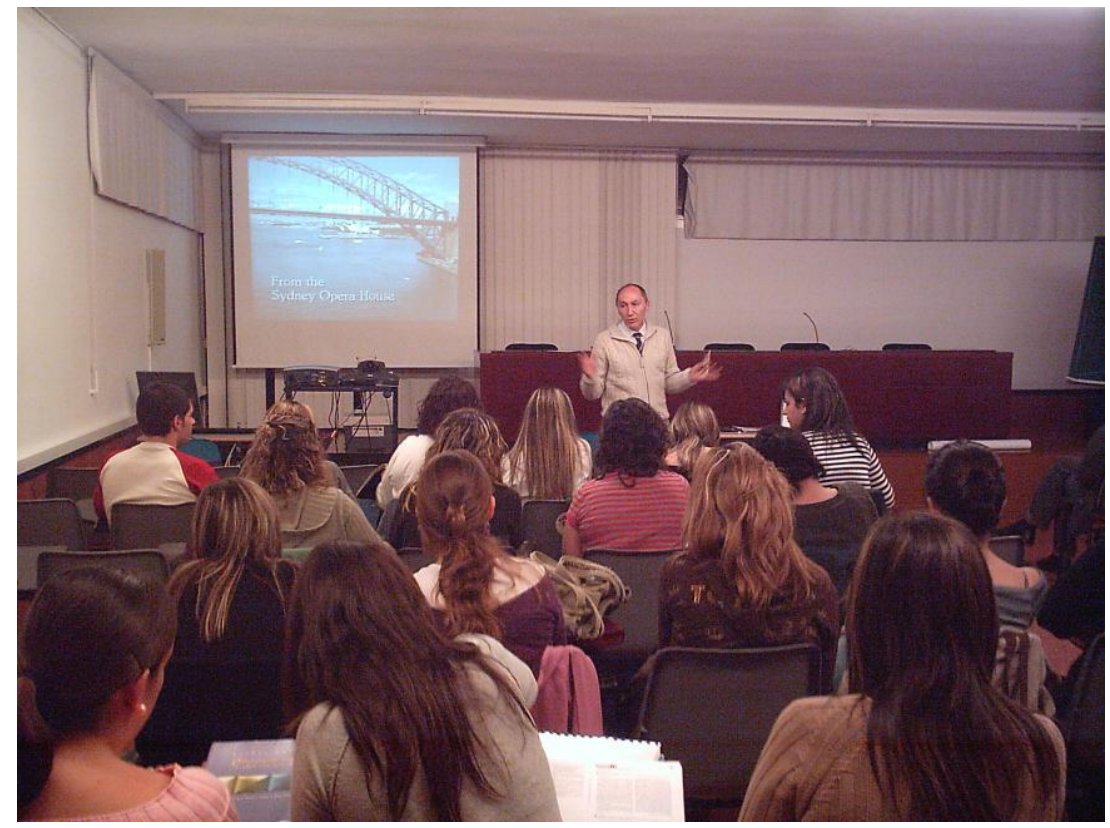

\section{"Una cultura de trabajo, deseos y realidades"}

Los itinerarios de la razón van precedidos de una hoja de ruta de luces y de sombras, del querer conocer ese camino para no perderse y tener memoria de nuestros aciertos y errores. Nos movemos con férrea voluntad aunque a menudo miremos hacia atrás con inquietud y culpabilidad o con autocomplacencia. He vivido intensamente mi tiempo y creo que mi aportación fue hacer de la Pedagogía una disciplina atractiva para los hombres y mujeres de este nuevo siglo, con nuevas formas didácticas tanto formales como espontáneas, e integradoras de los recursos que aparecen en esta ola tecnológica imparable.

Cuando era niño pasaba las hojas de aquella enciclopedia de láminas coloristas, y cada cuadro, ya fuera de un ornitorrinco o de una Venus, de héroes con flechas clavadas, o santas con flores en su falda, me excitaba la imaginación. Mis padres, por el contrario, querían que reconociese delante de las visitas el autor, la escuela o las principales características de una u otra época. 
He recordado los libros leídos, algunos como Gargantúa o la Divina Comedia con grabados apocalípticos, me los sacaba un padre jesuita de la biblioteca "secreta" del colegio; en ellos encontré de nuevo los mitos y los símbolos del progreso, con más vida que en muchos documentales de la televisión.

Por estas primeras experiencias, he creído en una forma de pedagogía como arte del discurso y sigo la técnica de los enormes retablos renacentistas, donde las ideas están plasmadas en un conjunto de imágenes de hechos y personajes de nuestra universal historia. Lipovetsky (1986) en su discutida obra La era del vacío también está de acuerdo en que cada generación se reconoce y encuentra su identidad en figuras mitológicas o legendarias que reinterpreta en función de los problemas del momento, y yo también me he detenido en estos mitos o alegorías: EDIPO, no olvidaré el día que estuve en la casa de Freud de Viena, yo mismo frente a esa esfinge que me pregunta, ese emblema universal del hombre frente a la autoridad, DIOS, ESTADO, PADRE...y los otros que me han querido gobernar. PROMETEO, el maestro que se sacrifica por dar las claves de la liberación. FAUSTO, no he querido vender mi alma, excepto cuando de ello dependía sobrevivir. NARCISO, mi yo egocéntrico discutiendo aun sin razón y comprometiendo mi estatus hasta el ridículo en este momento en que el capitalismo autoritario cede frente a la hedonista sociedad de consumo, y el individualismo ético se desliza hacia una personalidad cada vez más alejada de valores sociales o morales. Y por fin SISIFO, cada año subiendo la piedra de un temario siempre insuficiente para dejarla caer sobre una clase de estudiantes absortos en sus circunstancias vitalistas, y de nuevo a empezar año tras año, con cada nuevo plan de estudios, inerme ante la sinrazón academicista o política.

Como Antinoo, a veces me he identificado hasta la desilusión con el destino del pueblo y los líderes que parecían honestos: es la renuncia al protagonismo histórico por creer que los poderes públicos cumplirán sus fines con decisión, y al final hacemos dios al héroe anónimo que ha cumplido con su deber en su vida y en su trabajo cotidiano.

Si tuviera que valorar mi vida profesional, pienso que he sido un funcionario disciplinado cumpliendo las tareas que me han sido asignadas por la universidad, siendo escrupuloso en la dedicación a las mismas con puntualidad y perseverancia, lo cual he completado muchas veces, y según los procesos sociales en que he estado inmerso, con otras iniciativas, muchas de ellas dependientes de mis aficiones personales y actividades ad hoc.

Ciencia, Arte y un decidido afán de progreso social, entendido como creía Durkheim, en la igualdad de oportunidades para el disfrute de los bienes culturales, han encaminado mis aportaciones en la educación superior, y de algunas quedará constancia en otras publicaciones. Pero si hay un punto al que posiblemente se refieran las generaciones de alumnos al citar mi labor académica en estos años, será al sentido que di a una educación democrática y participativa independientemente de los orígenes de cada cual, incluyendo los alumnos de otras culturas, respetando 
cada persona y la inviolabilidad de su conciencia, como apunté en la obra Educación para la acción crítica (UOC, 2012).

La cultura no solo es un aprendizaje social, es un estilo de vida, y cada cual elige su forma de hacerlo que se refiere también a la estructura familiar que elegirá. Los rasgos culturales, las preferencias y los prejuicios forman parte de nuevos valores, algunos han sido marcados en nuestro instinto básico, como algunos deseos y fobias; otros, por las normas convencionales de los grupos sociales, incluso por la conciencia nacional, pero hay un momento en que cada uno elige y se arriesga a vivir con un código propio más allá de las diferencias genéricas o raciales que practican los alopátridas, encerrados en mundos pequeños.

Los elementos básicos, sean críticos, tecnológicos o estéticos, como yo lo entendí e intenté estructurarlos, estarán presentes en el continuismo pedagógico de las sociedades postmodernas, y compartirán los estilos docentes con el discurso científico, con la insistencia en utilizar un lenguaje formal, al que siempre acompañé con sentido del humor, ironía y algún sarcasmo que levanta ampollas en algunas personas. La imaginación no oculta la realidad sino que la hace grácil y hermosa.

\section{“LA GALAXIA DE LOS LIBROS se liquida en pequeñas nubes on line"}

Las nuevas tecnologías se muestran triunfantes colonizando las mentes incluso en esferas universitarias, como hicieron las religiones, los nacionalismos o el materialismo dialéctico mal usado. Los creadores de enlaces y herramientas, para mantener conectadas y utilizadas las nuevas ideas, atrapan a los individuos, personas de todo tipo, reciclando funciones para entretener o despolitizar hasta la inconsciencia. Pero algunos acontecimientos recientes sociológicamente alteran el equilibrio tradicional entre dirigentes y dirigidos.

En La Galaxia Gutenberg, génesis del hombre tipográfico, Marshall McLuhan comenzó un gigantesco ensayo que revolucionó conceptos psicológicos y sociológicos de nuestra cultura occidental. McLuhan, renueva la interpretación de la historia afirmando que los grandes cambios sociales tienen su origen en la evolución de las tecnologías, entre las cuales la más condicionante, según él, fue el desarrollo de la imprenta y su evolución, en contraste con la cultura anterior que era oral. Según este autor, nuestra cultura tipográfica condiciona nuestra manera de pensar en forma lineal, anterior al desarrollo de nuestros medios electrónicos que lo harían en forma multifuncional, creando una suerte de simultaneidad que modifica dramáticamente nuestras percepciones como individuos. La lectura de otros libros fue el origen de la libertad de conciencia; la informática, de la autodidaxia y el hipertexto.

Nuestros sentidos corporales no son sistemas cerrados, sino que constantemente se traducen unos en otros en esa experiencia que llamamos consciencia. 
Mi interés, muy anterior a las "competencias" que quiere implantar el Plan Bolonia, fue crear conciencia por medio de las lecturas seleccionadas de los clásicos, desde los discursos de Cicerón (Quousque tandem abutere, Catilina, patientia nostra?) hasta los artículos y hashtags más irritantes de los "indignados". Fomentando a la vez su expresividad con el discurso oral y las discusiones dialécticas de la más pura escolástica, en clase se consigue crear corrientes de opinión que darán lugar a contrastadas experiencias pedagógicas.

En el Renacimiento la Iglesia, como también los islamistas, desde el mismo razonamiento teologicista, plantearon un proceso maniqueísta sobre que libros estarían permitidos (halal) y cuales prohibidos (haram), la censura y la inquisición se encargaban de esa tarea. Pero con la Ilustración, la forma de enfocar el pensamiento crítico fue diferente: admitía un dualismo, posición más agnóstica que la anterior pues el mismo hecho podía ser juzgado a la luz de la razón, lo ideal, y de la experiencia, lo real. Kant en sus numerosas obras en torno a la epistemología admite las diversas vías para adquirir conocimientos y formular "juicios" que dirigirán nuestras conductas, fundamentalmente éticas. Hegel avanza esa dialéctica moderna y en su Fenomenología del espíritu, como comenta Ferrater Mora, lo expresa con claridad: "La Idea en su ser en y para sí misma, al regresar del gran círculo en que, a partir de su ser en sí, recorrió los sucesivos momentos de su alteridad, constituye el objeto de la filosofía del espíritu. También en ella alcanza el Espíritu su pura y absoluta interioridad a través de un movimiento dialéctico en el cual el Espíritu como ser en sí es Espíritu subjetivo, como ser fuera de sí o por sí es Espíritu objetivo, y como ser en y para sí mismo es Espíritu absoluto. El Espíritu subjetivo es el espíritu individual, afincado en la naturaleza humana y en marcha continua hacia la conciencia de su independencia y libertad. A través de los grados de la sensación y del sentimiento, fases corporales que facilitan el acceso a la entrada en sí mismo, el Espíritu subjetivo llega a su conciencia, al entendimiento y finalmente a la razón. Libertado el Espíritu subjetivo de su vinculación a la vida natural, puesto como conciencia pura de sí mismo, se realiza en el Espíritu objetivo como Derecho, como moralidad y como eticidad. El Derecho constituye el grado inferior de las realizaciones del Espíritu objetivo, porque afecta únicamente a la periferia de la individualidad: la moralidad, en cambio, agrega a la exterioridad de la ley la interioridad de la conciencia moral. Pero esta interioridad, cuyo carácter subjetivo la hace inadecuada para la plena realización del Espíritu objetivo, debe dar paso inmediato a la eticidad, a la ética objetiva que se realiza en lo universal concreto de la familia, de la sociedad y del Estado, síntesis de la exterioridad de lo legal y de la arbitrariedad subjetiva de lo moral. El Estado no es un mero protector de los intereses del individuo como tal, de su libertad subjetiva, sino la forma más elevada de la ética objetiva, la plenitud de la idea moral y la realización de la libertad objetiva. El Estado es el universal concreto, la verdadera síntesis de la oposición entre la familia y la sociedad civil, el punto de detención y de reposo del espíritu objetivo. La síntesis del Espíritu subjetivo y el objetivo es el Espíritu absoluto, que a su vez se auto-despliega en la intuición de sí mismo como arte, en la representación de sí mismo como religión y en el absoluto conocimiento de sí mismo como filosofía." 
Así se instaura la política de los intereses individuales congregados en la soberanía popular, el interés general, que conforman los movimientos sociales y dan legitimidad a las fuerzas sociales mayoritarias.

La universidad en su actual "pesebrismo" ha rehuido de la acción política trasformadora para refugiarse en técnicas de gestión y control de la más perversa organización empresarial. Ha reforzado las diferencias entre directores y dirigidos y a convertido en asimétricos los valores de la investigación y la educación.

Por eso, desde una cierta situación irreductible, he tenido la necesidad de dejar que entrará la luz por las ventanas (Windows) de la "clase" (aula abierta), y por ella hemos mirado a los múltiples escenarios de lo posible y lo imposible: junto a la dialéctica del discurso y el contraste con obras del pensamiento moderno, el cine y su dramaturgia nos ha quitado vendas de los ojos para ver otros mundos y otros dramas, desde la angustia existencial a la conciencia de clase.

Como en las viejas disciplinas, la música ha sido un recurso sublime, al que ni los dioses se han podido resistir cuando las palabras no eran suficientes para expresar el sufrimiento, el amor y el éxtasis. Aún recuerdo lo que escribí en Comunicació Educativa (2004):

La música no actua solament quan s'utilitza com a forma d'alienació, i els seus valors abstractes i universals són pertorbats per les connotacions propagandístiques del llenguatge, de les paraules vertaderes o fingides, i de les imatges que li donen una força concreta i la redueixen a un realisme gairebé salvatge. Al saló dels miralls del Liceu de Barcelona podem llegir als frisos que coronen als genis de l'art musical i escènic:

"La música es el único placer de los sentidos del cual el vicio no puede abusar. La música es la palabra del alma sensible como la palabra es el lenguaje del alma intelectual".

La Pedagogía sigue siendo herencia de la sàtira de Juvenal:"Mens sana in corpore sano" que se convierte en fín en la educación del nuevo profesorado. 